\title{
South American and African Grass Species Cope Differently With Soil Water Availability
}

\author{
Carolina Musso ${ }^{1,2}$, Glória Pinto ${ }^{2}$, Heloisa Sinatora Miranda ${ }^{1}$, Rhaul Oliveira ${ }^{3}$, Carlos Correia ${ }^{4}$, \\ José Moutinho-Pereira ${ }^{4}$, Amadeu M. V. M. Soares ${ }^{2,5} \&$ Susana Loureiro $^{2}$ \\ ${ }^{1}$ Departamento de Ecologia, Universidade de Brasilia, DF, Brasilia, Brazil \\ ${ }^{2}$ Departmento de Biologia \& CESAM (Centre for Environmental and Marine Studies), Universidade de Aveiro, \\ Aveiro, Portugal \\ ${ }^{3}$ Faculdade de Tecnologia, Universidade Estadual de Campinas, Limeira, SP, Brazil \\ ${ }^{4}$ Centre for the Research and Technology of Agro-Environment and Biological Sciences (CITAB), Universidade \\ de Trás-os-Montes e Alto Douro, Vila Real, Portugal \\ ${ }^{5}$ Programa de Pós-Graduação em Produção Vegetal, Universidade Federal do Tocantins, Campus de Gurupi, \\ Gurupi, TO, Brazil \\ Correspondence: Carolina Musso, Departamento de Ecologia, Universidade de Brasilia, DF, Brasilia, Brazil. Tel: \\ 55-613-107-3004. E-mail: cmusso86@gmail.com.br
}

Received: May 4, 2019 Accepted: June 18, $2019 \quad$ Online Published: August 15, 2019

doi:10.5539/jas.v11n13p64 URL: https://doi.org/10.5539/jas.v11n13p64

\begin{abstract}
African grasses pose a serious threat to the integrity and conservation of the Cerrado biome (Brazilian savanna). This study evaluated the responses of an invasive (Melinis minutiflora) and a native (Schizachyrium microstachyum) grass species to water availability, simulating natural situations. Individuals of the two species were submitted to different soil moisture levels, simulating from drought to flood, for four weeks in a climate-control chamber. Several morphological and physiological parameters were assessed: shoot height, biomass, number of leaves, tillers, leaf area, leaf gas exchange and chlorophylla fluorescence parameters, photosynthetic pigments and MDA concentration and GST, G-POX, APX and CAT activities. Significant differences were observed between species and among soil moisture levels, being drought more detrimental to both. Although both species were able to cope with water stress conditions and performed best at $80 \%$ soil moisture, the invasive species grew more rapidly, showed higher net photosynthetic rates in all circumstances and showed less evidence of stress. Variations in soil moisture levels promoted a stronger response in the native species, reducing biomass accumulation and triggering a stronger biochemical response than in the invasive species.
\end{abstract}

Keywords: alien plants, biomarkers, drought, flood, Melinis minutiflora, Schizachyrium microstachyum

\section{Introduction}

The savanna-like Brazilian Cerrado biome originally occupied over 25\% of Brazilian territory and is known for high levels of biodiversity and endemism of plant species. This biome is considered one of the world's most critical ecosystems in terms of conservation (Myers, R. A. Mittermeier, C. G. Mittermeier, Fonseca, \& Keny, 2000). Many Cerrado species are currently at risk due to the introduction of exotic species, mostly to convert natural areas into pastures. Some exotic species can become invasive and threaten Cerrado biodiversity by excluding native species when competing for natural resources (Pivello, Shida, \& Meirelles, 1999; Zenni \& Ziller, 2011; Damasceno, Souza, Pivello, Gorgone-Barbosa, Giroldo, \& Fidelis, 2018). Furthermore, invasive plant species have been reported to cause changes in the microclimate and in the natural cycles of disturbance, affecting the functioning of the ecosystem by accumulating large amounts of biomass (D'Antonio \& Vitousek, 1992; Silva \& Haridasan, 2007). African grasses are one of the most aggressive invaders in the Cerrado; they are opportunistic (Barger, D'Antonio, Ghneim, \& Cuevas, 2003; Martins, 2006) and are able to displace native grasses and form monospecific stands (Pivello et al., 1999; Zenni \& Ziller, 2011; Damasceno et al., 2018). In this biome, one of the most pervasive invasive grasses is the molasses grass Melinis minutiflora P. Beauv., native to Africa. The herbaceous layer in Cerrado shows a high density and frequency of grasses, and over 600 native 
grass species have been described (Munhoz \& Felfili, 2006). However, areas invaded by M. minutiflora undergo a sharp decrease in species richness, along with an increase in biomass accumulation (Pivello et al., 1999; Martins, 2006; Hoffman \& Haridassan, 2008).

In the Cerrado, the native and invasive grasses must cope with a broad range of environmental factors, especially soil water availability. The Cerrado climate has two well-marked seasons. The mean annual precipitation is 1600 $\mathrm{mm}$, over $90 \%$ of which occurs from October to April (rainy season), with almost no rainfall from May to September (dry season) (Eiten, 1972). Along with the high transpiration rates typical of plants in tropical areas and the good drainage of Cerrado soils, the dry season imposes a strong water stress on Cerrado plant communities (Quesada, Miranda, Hodnett, Santos, Miranda, \& Breyer, 2004; Rossato, Silva, Villalobos-Vega, Sternberg, \& Franco, 2012). The vegetation consists of different physiognomies, from closed-canopy sites (cerradão) to savanna formations (cerrado sensu stricto) and open sites with scattered trees and shrubs (campo-sujo and campo-limpo). The distribution of these physiognomies is determined by, among other factors, the distance from the water table (Coutinho, 1978; Rossato et al., 2012). In the campo-sujo and campo-limpo, the herbaceous layer is more important than in the other physiognomies, and over $70 \%$ of the herbaceous species are grasses (Ribeiro \& Walter, 1998; Munhoz \& Felfili, 2005).

Plant growth is influenced by water availability (both excess water and water deficit). This ecosystem may, therefore, be more or less susceptible to invasion in different areas and at different times of year, depending on how the native and invasive species cope with environmental stress factors such as soil water availability (Alpert, Bone, \& Hoezapfel, 2000; Meekins \& McCarthy, 2001; Daehler, 2003; Funk, Cleland, Suding, \& Zavaleta, 2008; Going, Hillerislambers, \& Levine, 2009). Thus, understanding the physiology of the invasive grasses in comparison with the natives under different conditions of soil water availability could be crucial for understanding competition dynamics and ecosystem vulnerability to invasion in future research.

The primary effect of drought is a reduction of the soil water potential, making it harder for roots to extract water. In contrast, with flooding the water availability is high, but the $\mathrm{O}_{2}$ availability for root respiration is restricted by its slow diffusion rate in water, limiting root growth (Bailey-Serres, Lee, \& Brinton, 2012). In both water-stress conditions, plants respond through diverse biochemical and morpho-physiological processes, including reductions in growth, photosynthesis and metabolism, stomatal closure, and increases in Reactive Oxygen Species (ROS) (Chaves, Maroco, \& Pereira, 2003; Bailey-Serres et al., 2012; Correia et al., 2014). Both water deficit and flooding conditions can lead to oxidative stress through overproduction of ROS in plant cells, which can damage cellular components, including DNA, proteins and membrane lipids (Mittler, Vanderauwera, Gollery, \& Van Breusegem, 2004; Suzuki, Koussevitzky, Mittler, \& Mittler, 2012). Furthermore, parameters related to the photochemical and photosynthetic changes, pigment concentration, as well as the protective mechanisms against oxidative damage are important indicators for deciphering the flooding and drought tolerance ability of a plant (Tester \& Basic, 2005; Bailey-Serres et al., 2012). Such differences among species might be major factors responsible for their different distribution patterns. Studying these parameters simultaneously may reveal underlying mechanisms of competition and help to more comprehensively explain their morphological responses, which in turn may be reflected in the ecological relationships between the species.

However, the role of physiological responses in determining the tolerance of grasses to water stress is far from clear. The main aim of the present study was to assess the effects of different soil moisture levels, simulating the natural conditions ranging from water deficit to flooding that they might experience in the Cerrado, on the morphological and physiological fitness of the native little bluestem grass Schizachyrium microstachyum (Desv. ex Ham.) Roseng. and the African molasses grass M. minutiflora. The several morpho-physiological and biochemical parameters assessed included growth, leaf mineral, and pigment concentrations, chlorophyll fluorescence and leaf gas-exchange parameters, lipid peroxidation and antioxidant enzymatic activities. The experimental trials used in this study were designed to simulate some of the environmental variations that these plants undergo in the field. The different soil moisture levels could be representative of the seasonal variations and the vegetation/topographic gradients. We attempted to answer the following questions: A) Do these species show morphological differences, such as biomass accumulation, in their stages of establishment? B) Do these parameters vary along a soil-moisture gradient? C) Can these differences (between species or soil-moisture levels) be related to physiological parameters such as assimilation rate, pigment concentration, and lipid peroxidation? 


\section{Method}

\subsection{Plant Material}

Schizachyrium microstachyum is a common native grass in the Cerrado, where it is abundant in all phytophyisiognomies (Filgueiras, 1992). Because of its high proportion of fertile seeds, it can reach an amount of germinated seeds per gram comparable to the values reported for invasive species such as M. minutiflora. Furthermore, both present a $\mathrm{C} 4$ metabolic pathway, being adapted to the areas with high incidence of solar radiation. Therefore, S. microstachyum is recommended for sowing in the restoration of Cerrado degraded areas and areas invaded by M. minutiflora (Carmona, Martins, \& Fávero, 1998; Aires, Sato, \& Miranda, 2013). Melinis minutiflora is one of the most pervasive invasive plants in the Cerrado. It was originally introduced in Brazil for use as livestock forage, at least as early as 1800 (Zenni \& Ziller, 2011). It threatens native biodiversity by competitively excluding native species (Pivello et al., 1999), producing massive amounts of biomass, up to two or three times the biomass of the native herbaceous layer (Martins, 2006).

Seeds were collected within the area of the Reserva Ecológica do Instituto Brasileiro de Geografia e Estatística,

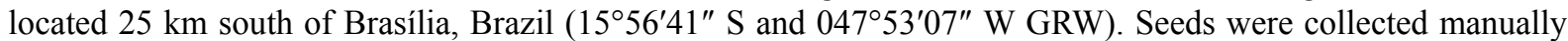
from May to July 2010, during the dispersal period (Almeida, 1995) and when one-third of the panicles had dispersed, to ensure that the maximum amount of seeds were mature. The collection took place in several patches within a continuous area of about 700 ha, by walking along imaginary transects within those patches (Carmona et al., 1998). All mature panicles were collected from all found individuals found of these two species until a minimum of $300 \mathrm{~g}$ of seeds were collected. Since variability in the germination of seeds from different sources, i.e. from individuals within a population or parts of an individual, has been reported (Cruz, Pérez, Velasco, \& Moreno, 2003; Moreira, Tavsanoglu, \& Pausas, 2012), panicles were pooled and dried at room temperature in the dark. The seeds were then separated, and stored in paper bags at room temperature until use (Carmona et al., 1998).

\subsection{Experimental Design}

For both species seeds, four samples of 100 seeds were removed randomly from the pooled seeds and germinated in Petri dishes with moistened cotton and filter paper, as described by Aires et al. (2013), in a $37^{\circ} \mathrm{C}$ : $22{ }^{\circ} \mathrm{C}$ and $10 \mathrm{~h}: 14 \mathrm{~h}$ light:dark temperature/photoperiod regime, to simulate soil temperatures at the onset of the rainy season (Andrade, Neto, \& Miranda, 2002). The 3-day old seedlings were carefully manually transplanted to experimental pots using tweezers and were individually placed in small grooves prepared in the soil surface, totalizing ten seedlings of the same species per pot. The pots measured $12.5 \mathrm{~cm}$ diameter $\times 15 \mathrm{~cm}$ height since, in the field, over $50 \%$ of root system of adult native and invasive species are concentrated (Barger et al., 2003; Fidelis, Lyra, \& Pivello, 2013). The pots contained a $500 \mathrm{~g}$ mixture of organic matter and mineral soil in the first $20 \mathrm{~cm}$ of soil (50:50 v:v, Simões \& Baruch, 1991), where soil moisture was maintained by capillary action, through a fiberglass wick (5 to $10 \mathrm{~mm} ø$ ) on the bottom of the pot (Loureiro et al., 2006). Seedlings were left to grow in monoculture in this constantly well-watered soil for four weeks in a climate-control chamber set at $28{ }^{\circ} \mathrm{C}$ and $12 \mathrm{~h}: 12 \mathrm{~h}$ light:dark photoperiod $\left(156 \pm 5.37 \mathrm{~W} \mathrm{~m}^{-2}\right)$. After this period the smallest seedlings were removed, and eight individuals were left per pot, to ensure that all replicates in the experiment would begin with the same amount of representative, healthy plants (adapted from IOS [International Organization for Standardization], 1995). Watering was then regulated to achieve the desired soil moistures $(10 \%, 40 \%, 80 \%$ and $120 \%$ of the soil's maximum water-holding capacity-WHC) which represent the gradual drying of Cerrado's surface soil during the dry season (Quesada et al., 2004). Four pots (experimental replicates) were used per treatment (total of 16 pots). Soil moisture levels were maintained by weighing the pots and adding the needed amount of water twice daily. As an adaptation from IOS (1995), the calculated amount of water was not corrected for the weight of the plant, which represents less than $1 \%$ soil weight.

After four weeks of growth under these conditions, several endpoints were assessed (adapted from IOS, 1995). First, chlorophyll fluorescence and gas exchange were measured as described below, and then the plants were harvested at soil level, their shoot extended length and fresh weight (FW) were measured, and the numbers of leaves and tillers were counted. Half of the plants collected were dried to determine the dry weight (DW), the shoot water content (DW basis) and nitrate and phosphate concentrations. The remaining plants were snap-frozen and stored at $-80{ }^{\circ} \mathrm{C}$ for biochemical assays. The roots were carefully washed and oven-dried. As it was not possible to separate the roots of each individual, the root:shoot ratio was estimated by dividing the mean dry root biomass measured in each pot $(n=8)$ by the mean shoot biomass $(n=4)$. 


\subsection{Gas Exchange Parameters}

One day before the plant material was sampled, the leaf gas exchange was measured in the oldest intact leaves of five plants $(n=5)$ representing all four experimental replicates in each treatment, totaling five measurements per treatment (one random pot was sampled twice, but from different individuals). Measurements were performed using a portable infrared gas analyzer (LCpro+, ADC BioScientific Ltd, Hoddesdon, UK), equipped with the broad leaf chamber operating in open mode under ambient conditions. Net photosynthetic rate $\left(\mathrm{A}, \mu \mathrm{mol} \mathrm{CO}_{2} \mathrm{~m}^{-2}\right.$ $\left.\mathrm{s}^{-1}\right)$, stomatal conductance $\left(\mathrm{g}_{\mathrm{s}}\right.$, mmol $\left.\mathrm{H}_{2} \mathrm{O} \mathrm{m}^{-2} \mathrm{~s}^{-1}\right)$, transpiration rate $\left(\mathrm{E}, \mathrm{mmol} \mathrm{H}_{2} \mathrm{O} \mathrm{m}^{-2} \mathrm{~s}^{-1}\right)$, intercellular $\mathrm{CO}_{2}$ content $\left(\mathrm{C}_{\mathrm{i}}, \mathrm{ppm}\right.$ ), instantaneous water-use efficiency (WUE, determined by the ratio of $\mathrm{A} / \mathrm{E}$ ) and $\mathrm{C}_{\mathrm{i}} / \mathrm{C}_{\mathrm{a}}$ ratio were determined.

To determine the saturation light intensity A/PPFD (photosynthetic photon-flux density; light-response curves of $\mathrm{CO}_{2}$ assimilation), curves were constructed with the following PPFD: 2000, 1500, 1000, 750, 500, 250, 100, 50 and $0 \mu \mathrm{mol} \mathrm{m}{ }^{-2} \mathrm{~s}^{-1}$. After A/PPFD data analysis, point measurements at saturation light intensity were performed at $750 \mu \mathrm{mol} \mathrm{m} \mathrm{m}^{-2} \mathrm{~s}^{-1}$. The following conditions were maintained inside the chamber during all measurements: air flow: $200 \mathrm{~mol} \mathrm{~s}^{-1}$; block temperature: $25^{\circ} \mathrm{C}$; and atmospheric $\mathrm{CO}_{2}$ and $\mathrm{H}_{2} \mathrm{O}$ concentration. Data were recorded when the measured parameters stabilized (2-6 $\mathrm{min})$.

\subsection{Chlorophyll Fluorescence}

One day before the plant material was sampled, chlorophyll fluorescence parameters were measured to calculate several variables, including the maximum quantum yield of PSII $\left(\mathrm{F}_{\mathrm{v}} / \mathrm{F}_{\mathrm{m}}\right)$ in dark-adapted leaves and the effective quantum yield $\left(\phi_{\mathrm{PSII}}\right)$ in light-adapted leaves, which are indicators of photochemical behavior in plants undergoing stress. Chlorophyll $\mathrm{l}_{\mathrm{a}}$ fluorescence parameters were measured on the adaxial side of eight mature leaves $(\mathrm{n}=8)$, pre-adapted to darkness or adapted to light, located at similar heights, representing all replicates in each treatment (two per pot), by using a pulse-amplitude-modulated fluorimeter (FMS 2, Hansatech Instruments, Norfolk, UK). Minimal fluorescence $\left(\mathrm{F}_{0}\right)$ was measured by applying a weak modulated light to leaves that had been pre-adapted to darkness for $30 \mathrm{~min}$. Maximal fluorescence $\left(\mathrm{F}_{\mathrm{m}}\right)$ was measured after applying a saturating pulse of white light $\left(15,000 \mu \mathrm{mol}\right.$ photons $\left.\mathrm{m}^{-2} \mathrm{~s}^{-1}\right)$ for $0.7 \mathrm{~s}$ to the same leaves. In the light-adapted leaves, steady-state fluorescence $\left(\mathrm{F}_{\mathrm{s}}\right)$ and maximum fluorescence $\left(\mathrm{F}_{\mathrm{m}}{ }_{\mathrm{m}}\right)$ were also measured, following the same methodology. Definitions of fluorescence parameters $\left(F_{v} / F_{m}, \phi_{P S I I}=\Delta F / F_{m}^{\prime}=\left(F_{m}{ }_{m}-F_{s}\right) / F_{m}{ }_{m}\right)$ were used as described by Van Kooten and Snel (1990), and non-photochemical quenching $\left.\left[\mathrm{NPQ}=\left(\mathrm{F}_{\mathrm{m}}-\mathrm{F}_{\mathrm{m}}{ }_{\mathrm{m}}\right) / \mathrm{F}_{\mathrm{m}}{ }_{\mathrm{m}}\right)\right]$ was calculated according to Bilger and Björkman (1990).

\subsection{Pigments}

Pigments were extracted from the leaves of the individual plants (five different individuals, from four different pots, where two individuals came from the same pot) in a solution of cold acetone with $50 \mathrm{mM}$ Tris buffer (pH 7.8; 80:20, v:v) and centrifuged at 5,000 g for $10 \mathrm{~min}$ Absorbance at 470, 537, 647 and $663 \mathrm{~nm}$ was determined in 96-well microplates, each sample in quadruplicate. The contents of chlorophyll a $\left(\mathrm{Chl}_{\mathrm{a}}\right), \mathrm{b}\left(\mathrm{Chl}_{\mathrm{b}}\right)$, carotenoids and anthocyanins were calculated with the following equations (Sims \& Gamon, 2002):

$$
\begin{gathered}
\mathrm{Chl}_{\mathrm{a}}=0.01373 \mathrm{~A}_{663}-0.000897 \mathrm{~A}_{537}-0.003046 \mathrm{~A}_{647} \\
\mathrm{Chl}_{\mathrm{b}}=0.02405 \mathrm{~A}_{647}-0.004305 \mathrm{~A}_{537}-0.005507 \mathrm{~A}_{663} \\
\text { Carotenoids }=\left\{\mathrm{A}_{470}-\left[17.1 \times\left(\mathrm{Chl}_{\mathrm{a}}+\mathrm{Chl}_{\mathrm{b}}\right)\right]-9.479 \times \text { Anthocyanins }\right\} / 119.26 \\
\text { Anthocyanins }=0.08173 \mathrm{~A}_{537}-0.00697 \mathrm{~A}_{647}-0.002228 \mathrm{~A}_{663}
\end{gathered}
$$

Before the calculations, the absorbance was corrected according to the path length traveled by the light in the samples in the microplates, to match the 1-cm cuvette used in the formula (Warren, 2008). The values were also used to calculate the $\mathrm{Chl}_{\mathrm{a}} / \mathrm{Chl}_{\mathrm{b}}$ ratio, to evaluate the balance between these two pigments.

\subsection{Nitrate and Phosphate Concentrations}

The concentrations of nitrate and phosphate in the plants were determined with the Hach Kit DR/2000 spectrophotometer. Dry leaves $(\mathrm{n}=3$, three different individuals, from four different pots) were extracted by homogenization in water with a mortar, in the proportion of 1:2 (mass:volume). The extract was filtered with activated charcoal and filter paper $(180 \mu \mathrm{m}$ thickness and $11 \mu \mathrm{m}$ pore size for particle retention). The filtered solution was then mixed with Hatch Kit reagents according to the protocols 8151 (Program 363) for nitrate and 8183 (Program 510) for phosphate. Results were presented as the percentage of dry weight. 


\subsection{Lipid Peroxidation}

Lipid peroxidation was estimated by measuring malondialdehyde (MDA) production (Dhindsa, Plumb-Dhindsa, $\&$ Throne, 1981). For the extraction of MDA, five leaf samples (five different individuals, $n=5$, from four different pots, where two individuals came from the same pot) weighing $0.5 \mathrm{~g}$ each were pulverized in a mortar with liquid nitrogen and then homogenized with $2.5 \mathrm{ml}$ of TCA solution (trichloroacetic acid at $0.1 \% \mathrm{w} / \mathrm{v}(\mathrm{g} / 100$ $\mathrm{ml})$ ). Then, an aliquot of the supernatant of the centrifuged samples was mixed with an equal volume of the reaction solution $(20 \%$ TCA $0.5 \%$ TBA $(w / v))$ and left to react for 30 min under heat $\left(95^{\circ} \mathrm{C}\right)$ and then cooled and re-centrifuged. The absorbance was measured in 1-ml cuvettes in a Thermo Fisher Scientific spectrophotometer (Waltham, USA) (Genesys 10-uv S). MDA concentration was estimated by subtracting the nonspecific absorption at $600 \mathrm{~nm}$ from the absorption at $532 \mathrm{~nm}$, using an absorbance coefficient of extinction $(\varepsilon), 155 \mathrm{mM}^{-1} \mathrm{~cm}^{-1}$.

\subsection{Antioxidant Enzymatic Activities}

Leaf samples (five different individuals, $\mathrm{n}=5$, from four different pots, where two individuals came from the same pot) were pulverized in a mortar with liquid nitrogen and then homogenized in the same mortar with a solution of $100 \mathrm{mM}$ phosphate buffer (pH 7.5) and $0.5 \mathrm{mM}$ EDTA. Samples were then centrifuged at 10,000 g for $20 \mathrm{~min}$ to separate the post-mitochondrial supernatant (Howcroft, Gravato, Amorim, Novais, Soares, \& Guilhermino, 2011). All methodologies were adapted for 96-well microplate reading. Glutathione S-transferase (GST) activity was measured based on the product of conjugation between the 1-chloro-2,4-dinitrobenzene and glutathione at $340 \mathrm{~nm}$ for $5 \mathrm{~min}$, according to the method of Habig and Jakoby (1981). Catalase (CAT) activity was determined by measuring the decomposition of the substrate $\mathrm{H}_{2} \mathrm{O}_{2}$ at $240 \mathrm{~nm}$ during $3 \mathrm{~min}$, based on the method described by Clairborne (1985). The reaction mixture contained $0.1 \mathrm{M}$ phosphate buffer ( $\mathrm{pH}$ 7.0) and 6 $\mathrm{mM} \mathrm{H} \mathrm{O}_{2}$, which started the reaction. L-ascorbate peroxidase (APX) activity was determined from oxidation of ascorbic acid $\left(\varepsilon=2.8 \mathrm{mM}^{-1} \cdot \mathrm{cm}^{-1}\right)$ to dehydroascorbate by $\mathrm{H}_{2} \mathrm{O}_{2}$, at $25{ }^{\circ} \mathrm{C}$, at $290 \mathrm{~nm}$, according to the method of Nakano and Asada (1981). For Guaiacol peroxidase (G-POX) determination, the reaction mixture consisted of 5 $\mu \mathrm{L}$ of plant extract in a $10 \mathrm{mM}$ phosphate buffer ( $\mathrm{pH}$ 6.1), $12 \mathrm{mM} \mathrm{H}_{2} \mathrm{O}_{2}$ and $96 \mathrm{mM}$ guaiacol solution. Absorbance was recorded at $470 \mathrm{~nm}$ for $5 \mathrm{~min}$, and the specific activity was calculated using the $26.6 \mathrm{mM}^{-1} \cdot \mathrm{cm}^{-1}$ molar extinction coefficient (Castillo, Penel, \& Greppin, 1984). Protein concentration was determined in quadruplicate by the Bradford method (Bradford, 1976), at $595 \mathrm{~nm}$, using bovine serum albumin (BSA) as the standard. GST and G-POX activities were corrected by protein content, and APX and CAT by the fresh weight. All measurements were made in a Labsystem Multiskan EX microplate reader (Labsystems Inc., Franklin, MA, USA).

\subsection{Data Analysis}

Under non-normality conditions, data were transformed by $\ln (\mathrm{x})$ or arcsine no meet normality assumption. When the parametric test assumption was not achieved after transformation, the parameter was analyzed with non-parametric test (Wilcoxon or Kruskal-Wallis followed by Dunn), for comparison between species and then among treatments within each species separetely. For the parameters that met the normality assumptions, means were compared using a factorial ANOVA. Species (the native S. michrostachyum and the invasive $M$. minutiflora) and water treatments $(10 \%, 40 \%, 80 \%, 120 \%)$ were the independent variables, and multiple comparisons were carried out using Tukey's HSD test.

For morphological parameters, each plant was considered as a sub-replicate, and the mean of the eight individuals was considered a replicate $(n=4)$. For the root:shoot ratio, as its calculation required the mean biomass ( $\mathrm{n}=4$ for shoot and $\mathrm{n}=8$ for root) of all individuals for each pot, thus four replicates were used ( $\mathrm{n}=4$, being each pot a replicate). Regarding the other parameters, each sampled individual was considered a replicate, as follows: in the case of the gas exchange $n=5$, and in the case of chlorophyll fluorescence $n=8$. For nitrate and phosphate $\mathrm{n}=3$, and for the oxidative stress parameters, $\mathrm{n}=5$. All data were analyzed using the $\mathrm{R}$ software (R 3.0.1 binary for Mac OS X 10.6). Graphs were produced using the collection of packages tidyverse (version 1.2.1; Wickham 2017).

\section{Results}

\subsection{Aerial Growth Traits}

Melinis minutiflora grew significantly more vigorously. The invasive species presented three times the dry weight, twice the number of leaves, at least one additional tiller per plant and a higher Root:Shoot ratio, while the native species bore a higher percentage of dry leaves (Figure 1, Table 1). Furthermore, mean $( \pm \mathrm{SD})$ general 
length was of $21.7 \pm 1.7 \mathrm{~cm}$ for M. minutiflora while it was of $10.3 \pm 2.2 \mathrm{~cm}$ for $S$. microstachyum $\left(\mathrm{H}_{1}=2.27, \mathrm{p}<\right.$ $0.001)$.

A

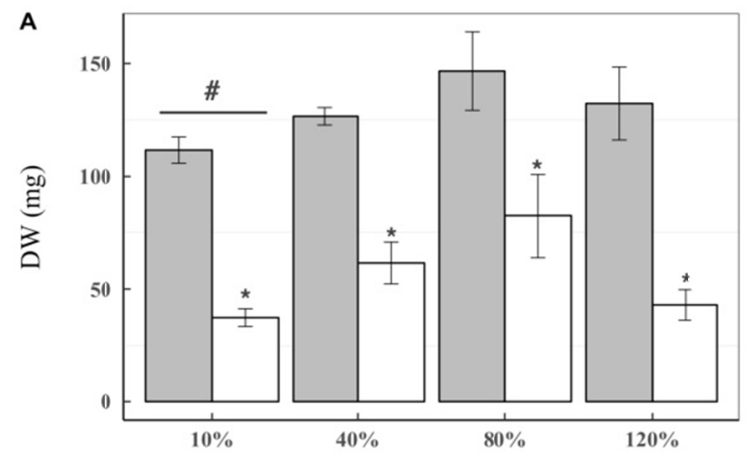

C

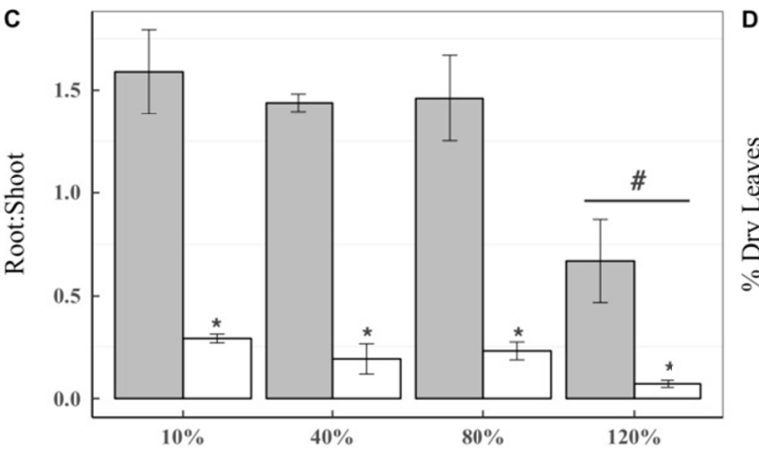

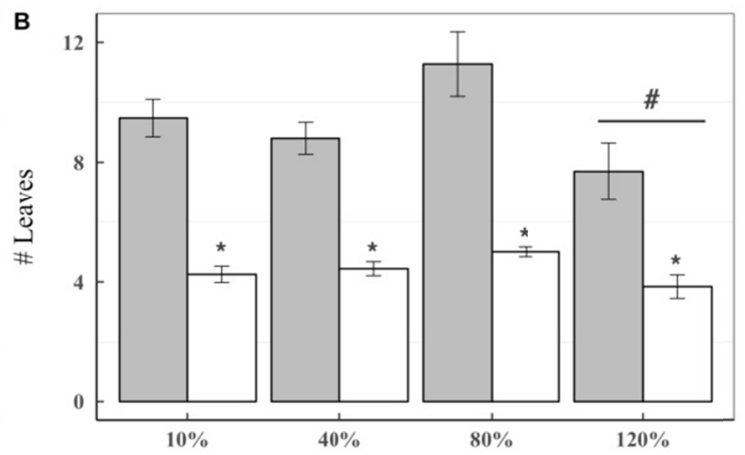

D

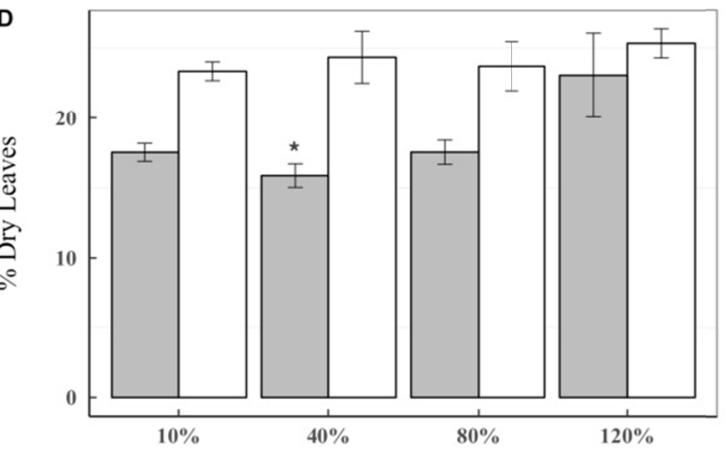

Moisture level

Figure 1. Mean values of morphological traits of the invasive (Melinis minutiflora, grey bars) and the Cerrado native (Schizachyrium microstachyum, white bars) grasses grown for 4 weeks in soil with different water contents (10, 40, 80 and 120\% maximum water-holding capacity). Vertical bars correspond to standard deviation of the mean $(n=4)$. A) DW = Dry weight; B) Number of Dry Leaves; C) Root to Shoot ratio; D) Percentage of Dry Leaves. Hashtags (\#) above the horizontal bars correspond to significant differences among soil moisture level. Asterisks $(*)$ correspond to differences between (Two-way ANOVA followed by Tukey's HSD, p $<0.05$ )

The two species responded similarly to the treatment (Table 1). The dry weight was significantly lower for plants growing at $10 \%$, while leaves were significantly fewer for $120 \%$ treatment (Figure 1), when compared to the optimum conditions of $80 \%$. For both species, moisture stress had no effects on the number of tillers, however the flood treatment $(120 \%$ WHC) significantly decreased the root: shoot ratio for both species (Figure 1). 
Table 1. Factorial ANOVA scores for the traits measured for the native Schizachyrium microstachyum and the invasive Melinis minutiflora under different soil water availability treatments $(10 \%, 40 \%, 80 \%$ and $120 \%)$ with a photoperiod of $12 \mathrm{~h}$ and temperatures of $22 / 28{ }^{\circ} \mathrm{C}$. Moisture and species were used as independent variables, followed by Tukey's HSD $(\alpha=0.05)$. The variables that are not presented here were analyzed with non-parametric tests and their results are presented within the text

\begin{tabular}{|c|c|c|c|c|c|c|}
\hline & \multicolumn{2}{|c|}{ Species } & \multicolumn{2}{|c|}{ Moist treatment } & \multicolumn{2}{|c|}{ Species $\times$ Moist treatment } \\
\hline & F1 & $\mathrm{p}$ & F3 & $\mathrm{p}$ & F3 & $\mathrm{p}$ \\
\hline Dry weight (DW) & 77.98 & $<0.001$ & 4.03 & 0.019 & 0.49 & 0.693 \\
\hline Number of leaves (NL) & 127.55 & $<0.001$ & 5.04 & 0.008 & 1.48 & 0.245 \\
\hline Number of tillers (NT) & 17.95 & $<0.001$ & 1.81 & 0.173 & 1.19 & 0.333 \\
\hline Dry leaves (DL) & 27.33 & $<0.001$ & 3.11 & 0.045 & 1.38 & 0.272 \\
\hline Root:Shoot (RS) & 141.04 & $<0.001$ & 7.59 & 0.002 & 3.24 & 0.051 \\
\hline Stomatal conductance $\left(\mathrm{g}_{\mathrm{s}}\right)$ & 1.81 & 0.188 & 2.74 & 0.059 & 4.63 & 0.008 \\
\hline Net assimilation rate (A) & 14.43 & 0.001 & 2.20 & 0.107 & 1.30 & 0.293 \\
\hline Water Use Efficiency (WUE) & 19.62 & $<0.001$ & 5.30 & 0.004 & 0.50 & 0.683 \\
\hline Internal/ambient $\mathrm{CO}_{2}\left(\mathrm{C}_{\mathrm{i}} / \mathrm{C}_{\mathrm{a}}\right)$ & 21.70 & $<0.001$ & 4.45 & 0.010 & 0.58 & 0.634 \\
\hline Phosphate & 0.05 & 0.833 & 9.85 & 0.001 & 8.09 & 0.002 \\
\hline Nitrate & 5.59 & 0.031 & 1.43 & 0.268 & 5.64 & 0.008 \\
\hline Chlorophyll a & 0.08 & 0.777 & 0.97 & 0.419 & 1.30 & 0.272 \\
\hline Chlorophyll b & 4.69 & 0.038 & 0.90 & 0.453 & 1.29 & 0.294 \\
\hline Carotenoids & 2.70 & 0.110 & 0.52 & 0.606 & 1.10 & 0.363 \\
\hline $\mathrm{Chl}_{\mathrm{a}} / \mathrm{Chl}_{\mathrm{b}}$ & 12.69 & 0.002 & 4.42 & 0.010 & 3.33 & 0.031 \\
\hline MDA & 120.50 & $<0.001$ & 3.56 & 0.025 & 4.00 & 0.016 \\
\hline GST & 211.49 & $<0.001$ & 3.52 & 0.026 & 1.04 & 0.387 \\
\hline CAT & 69.55 & $<0.001$ & 6.50 & 0.001 & 7.45 & 0.001 \\
\hline G-POX & 0.71 & 0.403 & 1.34 & 0.278 & 3.39 & 0.099 \\
\hline APX & 46.04 & $<0.001$ & 1.68 & 0.191 & 4.25 & 0.012 \\
\hline
\end{tabular}

\subsection{Leaf Gas-Exchange Parameters}

Leaf gas-exchange, parameters (Figure 2) showed significant differences between species for most parameters (Table 1). The invasive species showed higher values of A than the native $(p<0.001$, Table 1$)$ being marginally different in optimum conditions $(80 \% \mathrm{WHC} p=0.07)$. The native and invasive species didn't differ for stomatal conductance $\left(\mathrm{g}_{\mathrm{s}}\right)$ but the native species showed significantly higher values of $\mathrm{g}_{\mathrm{s}}$ during flood than during optimum conditions $(\mathrm{p}=0.006)$. WUE was affected significantly by the soil moisture for the native species, and values were higher for the invasive species $(p<0.001)$, especially at $120 \%$ WHC. Regarding $\mathrm{C}_{\mathrm{i}} / \mathrm{C}_{\mathrm{a}}$, the ratio was higher for the native species $(\mathrm{p}<0.001)$ and increased with flood $(\mathrm{p}=0.013)$.

\subsection{Chlorophyll Fluorescence}

Both the maximum quantum yield $\left(\mathrm{F}_{\mathrm{v}} / \mathrm{F}_{\mathrm{m}}\right)$ and the effective quantum yield $\left(\phi_{\mathrm{PSII}}\right)$ differed between species $(\mathrm{W}=$ 955.5, $\mathrm{p}<0.001 ; \mathrm{W}=893, \mathrm{p}<0.001$, respectively). The maximum quantum yield for the native species was lowest at $40 \%$ WHC $\left(\mathrm{H}_{3}=18.54, \mathrm{p}<0.001\right)$, while for the invasive species, $\mathrm{F}_{\mathrm{v}} \mathrm{F}_{\mathrm{m}}$ was higher in $10 \%$ and $40 \%$ than at $80 \%$ and $120 \%\left(\mathrm{H}_{3}=13.53, \mathrm{p}<0.01\right)$. The values of the effective quantum yield $\left(\phi_{\mathrm{PSII}}\right)$ were not affected by soil moisture level for the invasive species, but was significantly lower for the native species at $40 \%\left(\mathrm{H}_{3}=\right.$ $9.84, p=0.02$ ) than in other moisture levels. The non-photochemical quenching (NPQ) was not affected by the treatments and did not differ between the species (Figure 3). 

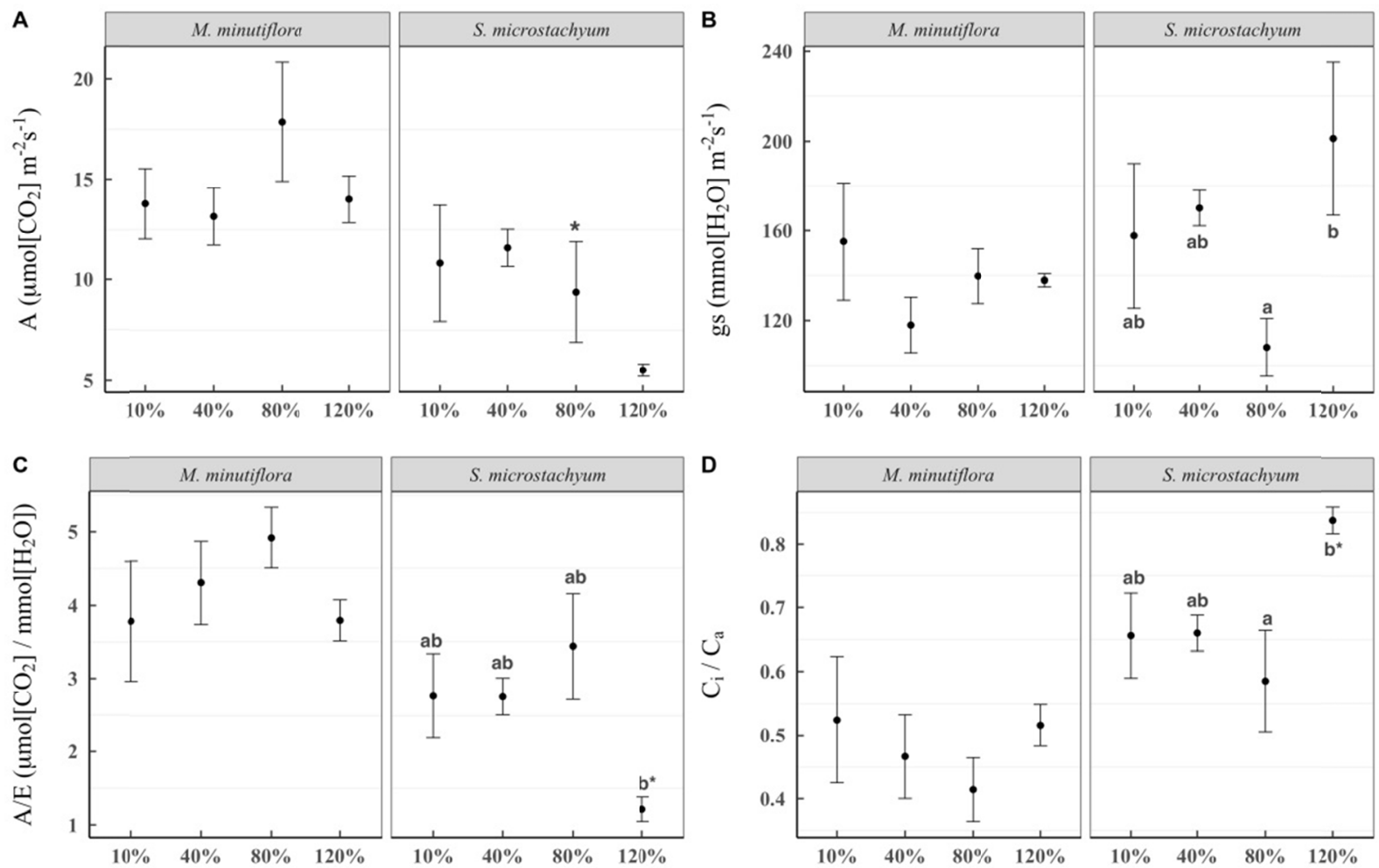

D
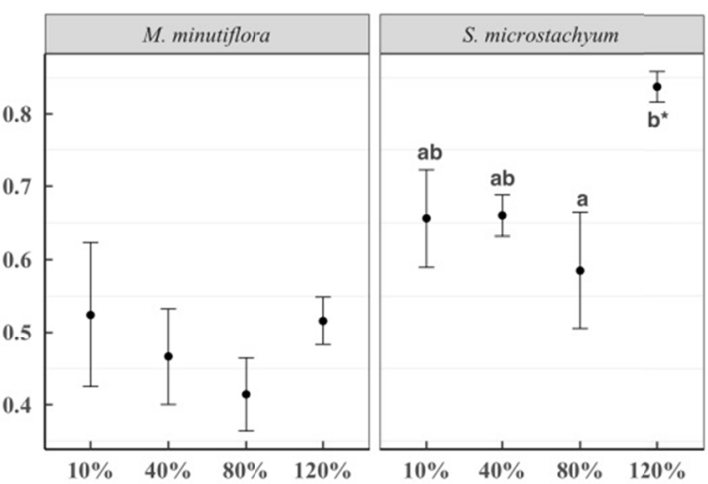

Moisture level

Figure 2. Mean values of gas exchange parameters reported for the invasive Melinis minutiflora and the Cerrado native Schizachyrium michrostachyum grasses grown for 4 weeks in soil with different water contents $(10 \%$, $40 \%, 80 \%$ and $120 \%$ maximum water-holding capacity). A) Net Photosynthetic rate; B) Stomatal conductance $\left(\mathrm{g}_{\mathrm{s}}\right.$ ); C) Instantaneous Water-Use Efficiency (WUE); D) Intercellular to Atmospheric $\mathrm{CO}_{2}$ concentration ratio $\left(\mathrm{C}_{\mathrm{i}} / \mathrm{C}_{\mathrm{a}}\right)$. Bars correspond to standard deviation $(\mathrm{n}=5)$. Different letters indicate significant differences among treatments within each species; asterisks indicate significant differences $(\mathrm{p}<0.05)$ or marginal differences $(\mathrm{p}<$

0.1 ) between species in that specific soil moisture level (Two-way ANOVA followed by Tukey's HSD) 
A

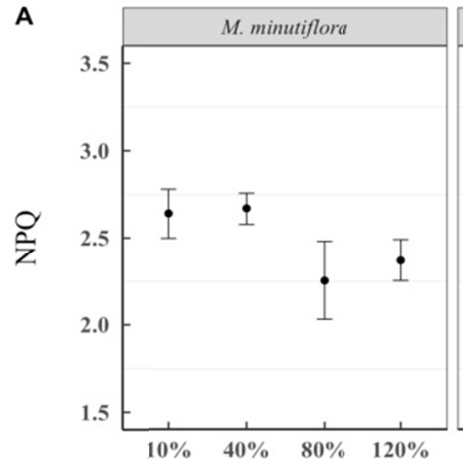

C

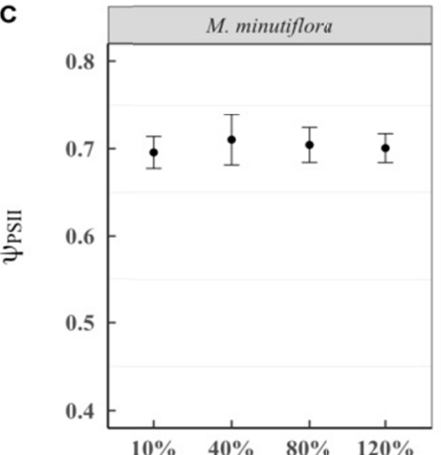

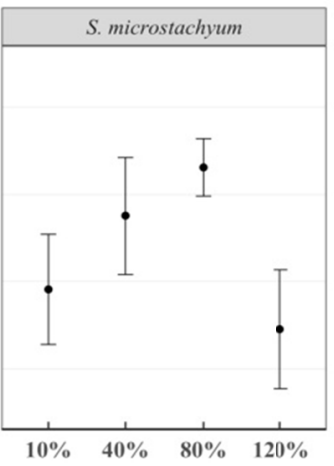

B
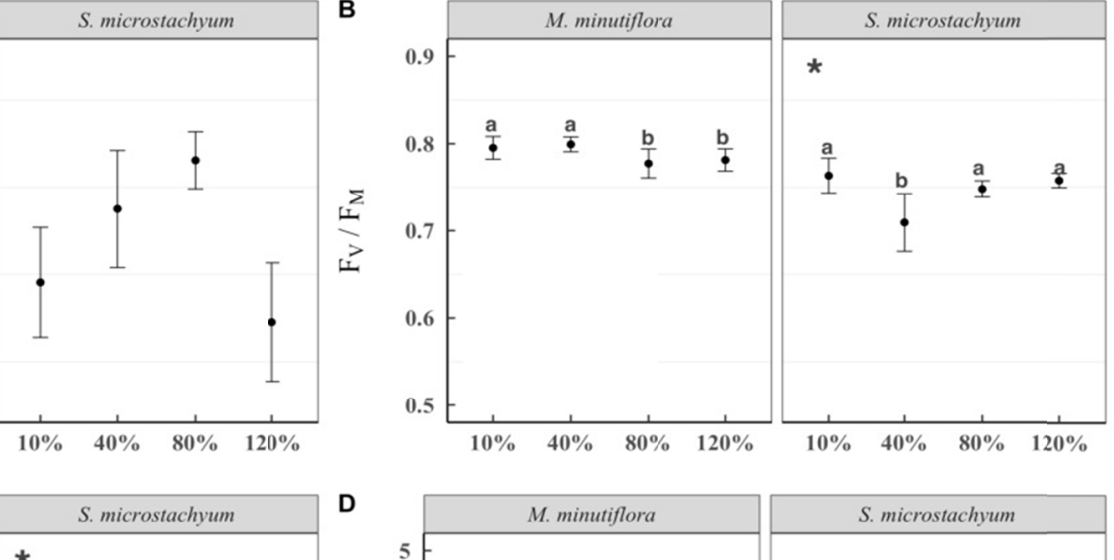

D

D

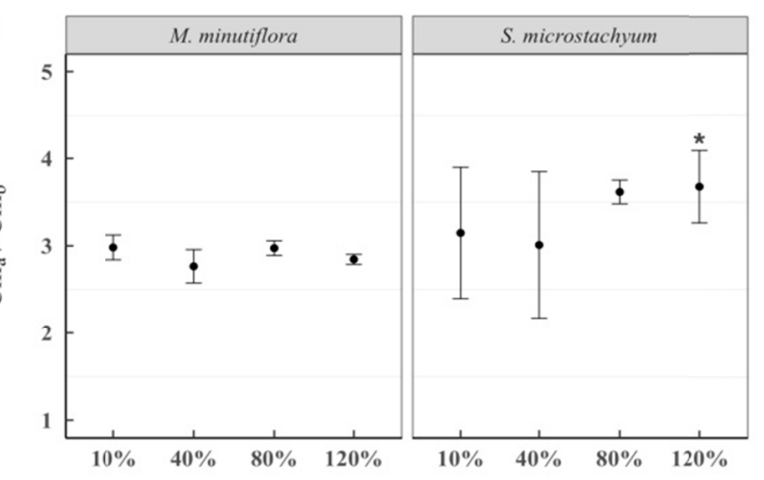

Moisture level

Figure 3. Mean values of fluorescence and pigment parameters for the invasive Melinis minutiflora and the Cerrado native Schizachyrium michrostachyum grasses grown for 4 weeks in soil with different water availability (10\%, 40\%, 80 and 120\% maximum water-holding capacity). A) Non-Photochemical Quenching

(NPQ); B) Effective Quantum Yield of Photosystem II ( $\left.\phi_{\text {PSII }}\right)$; C) Optimum Quantum Yield $\left(\mathrm{F}_{\mathrm{v}} / \mathrm{F}_{\mathrm{m}}\right)$; D) Chlorophylla to Chlorophyllb ratio $\left(\mathrm{Chl}_{\mathrm{a}} / \mathrm{Chl}_{\mathrm{b}}\right)$. Bars correspond to standard deviation $(\mathrm{n}=8)$. Different letters indicate significant differences among treatments (Kruskal-Wallis test, $\mathrm{p}<0.05$ ); asterisks indicate differences

between species (Wilcoxon test, $\mathrm{p}<0.05$ ) or significant differences between species for that specific soil moisture level (Two-way ANOVA followed by Tukey's HSD, $\mathrm{p}<0.05$ )

\subsection{Pigments}

Pigment concentration did not differ significantly between the species (Tables 1 and 2). However, the $\mathrm{Chl}_{\mathrm{a}} / \mathrm{Ch}_{\mathrm{b}}$ ratio was significantly higher for the native species at $120 \%$ WHC than for the invasive species.

\subsection{Nitrate and Phosphate Concentrations}

A significant interaction between species and soil moisture was observed (Tables 1 and 2) for phosphate and nitrate contents. This interaction may reflect the significantly higher amount of nitrate for the invasive species under drought conditions. 
Table 2. Leaf nutrients and leaf pigments of native Schizachyrium microstachyum and invasive Melinis minutiflora grasses under different soil water availability treatments $(10,40,80$ and $120 \%)$ in a photoperiod of $12 \mathrm{~h}$ and temperatures of $22 / 28^{\circ} \mathrm{C}$ (means $\pm \mathrm{SD}$ ). Asterisks indicate significant differences between species; letters indicate differences among soil moisture levels. $(\mathrm{FW}=$ fresh weight, $\mathrm{DW}=$ dry weight $)$ Factorial ANOVA with moisture and species as independent variables, followed by Tukey's HSD $(\alpha=0.05)$

\begin{tabular}{|c|c|c|c|}
\hline Endpoint & Treatment & M. minutiflora & S. microstachyum \\
\hline \multirow[t]{4}{*}{ Leaf nitrate $(\% \mathrm{DW})$} & $10 \%$ & $0.82( \pm 0.16)$ & $0.36( \pm 0.05)^{*}$ \\
\hline & $40 \%$ & $0.54( \pm 0.03)$ & $0.56( \pm 0.11)$ \\
\hline & $80 \%$ & $0.54( \pm 0.04)$ & $0.67( \pm 0.03)$ \\
\hline & $120 \%$ & $0.56( \pm 0.06)$ & $0.36( \pm 0.02)$ \\
\hline \multirow[t]{4}{*}{ Leaf phosphate $(\% \mathrm{DW})$} & $10 \%$ & $0.12( \pm 0.01)$ & $0.07( \pm 0.01) \mathrm{a}$ \\
\hline & $40 \%$ & $0.12( \pm 0.01)$ & $0.14( \pm 0.02) \mathrm{ab}$ \\
\hline & $80 \%$ & $0.13( \pm 0.01)$ & $0.18( \pm 0.01) b$ \\
\hline & $120 \%$ & $0.12( \pm 0.01)$ & $0.10( \pm 0.01) \mathrm{a}$ \\
\hline \multirow[t]{4}{*}{ Chlorophyll a $\left(\mu \mathrm{mol} \mathrm{gFW}^{-1}\right)$} & $10 \%$ & $1.0( \pm 0.09)$ & $1.0( \pm 0.14)$ \\
\hline & $40 \%$ & $0.9( \pm 0.09)$ & $1.1( \pm 0.15)$ \\
\hline & $80 \%$ & $1.0( \pm 0.15)$ & $1.2( \pm 0.22)$ \\
\hline & $120 \%$ & $1.1( \pm 0.09)$ & $0.75( \pm 0.14)$ \\
\hline \multirow[t]{4}{*}{ Chlorophyll b $\left(\mu \mathrm{mol} \mathrm{gFW}^{-1}\right)$} & $10 \%$ & $0.33( \pm 0.03)$ & $0.21( \pm 0.06)$ \\
\hline & $40 \%$ & $0.33( \pm 0.03)$ & $0.31( \pm 0.07)$ \\
\hline & $80 \%$ & $0.35( \pm 0.05)$ & $0.34( \pm 0.06)$ \\
\hline & $120 \%$ & $0.37( \pm 0.03)$ & $0.21( \pm 0.04)$ \\
\hline \multirow[t]{4}{*}{ Carotenoids $\left(\mu \mathrm{mol} \mathrm{gFW}^{-1}\right)$} & $10 \%$ & $0.66( \pm 0.06)$ & $0.57( \pm 0.07)$ \\
\hline & $40 \%$ & $0.64( \pm 0.07)$ & $0.65( \pm 0.07)$ \\
\hline & $80 \%$ & $0.72( \pm 0.09)$ & $0.70( \pm 0.11)$ \\
\hline & $120 \%$ & $0.77( \pm 0.08)$ & $0.52( \pm 0.07)$ \\
\hline
\end{tabular}

\subsection{Lipid Peroxidation}

The results for lipid peroxidation, expressed as the MDA concentration, are listed in Table 3. There was a significant interaction between treatment and species for the MDA concentration $(p<0.0001)$. The native species showed higher concentrations of MDA for all treatments except at $80 \% \mathrm{WHC}$. The MDA in the native species was more than double the concentrations measured in M. minutiflora (Tables 1 and 3). However, only the native species showed a response to drought stress, with significantly higher levels of MDA in the $10 \%$ treatment.

\subsection{Enzyme Activities}

APX activity differed between the species, and the native species tended to show higher activity. There was a significant interaction between species and treatment $(\mathrm{p}=0.012$, Tables 1 and 3$)$, and the APX activity tended to vary more with soil moisture in the invasive species. GST activity was affected by the moisture treatment $(\mathrm{p}=$ 0.026 , Tables 1 and 3$)$, and the native species showed higher values $(\mathrm{p}<0.001)$ for all treatments. CAT activity showed an inverse pattern to the GST and APX activities. The invasive species showed the highest activity for this enzyme (CAT) and also showed an increase in the driest treatment, which was not observed in the native species (Tables 1 and 4). On the other hand, the native species seemed to show higher activities in the wetter treatments, as suggested by the significant interaction between species and treatment $(p=0.001)$. 
Table 3. MDA and enzymatic activity of native Schizachyrium microstachyum and invasive Melinis minutiflora grasses under different soil water availability treatments $(10 \%, 40 \%, 80 \%$ and $120 \%)$ in a photoperiod of $12 \mathrm{~h}: 12$ $\mathrm{h}$ dark:light and temperatures of $22 / 28{ }^{\circ} \mathrm{C}$ (means $\left.\pm \mathrm{SD}\right)$. Asterisks indicate significant differences between species; letters indicate differences among soil moisture levels. (FW = Fresh weight). Factorial ANOVA using moisture and species as independent variables, followed by Tukey's HSD $(\alpha=0.05)$

\begin{tabular}{|c|c|c|c|}
\hline Biomarker & Treatment & M. minutiflora & S. microstachyum \\
\hline \multirow{4}{*}{ MDA $\left(\mathrm{mmol} \mathrm{gFW}^{-1}\right)$} & $10 \%$ & $4.15( \pm 0.47)$ & $14.25( \pm 1.00) b^{*}$ \\
\hline & $40 \%$ & $3.86( \pm 0.50)$ & $10.30( \pm 1.74) \mathrm{a}^{*}$ \\
\hline & $80 \%$ & $4.36( \pm 0.25)$ & $3.86( \pm 0.50) \mathrm{a}$ \\
\hline & $120 \%$ & $3.69( \pm 0.18)$ & $11.52( \pm 1.29) \mathrm{a}^{*}$ \\
\hline \multirow[t]{4}{*}{$\operatorname{GST}\left(\eta \mathrm{mol} \mathrm{ml} \mathrm{prot}^{-1} \mathrm{~min}^{-1}\right)$} & $10 \%$ & $1.33( \pm 0.25)$ & $5.41( \pm 0.58)^{*}$ \\
\hline & $40 \%$ & $0.91( \pm 0.19)$ & $3.98( \pm 0.31)^{*}$ \\
\hline & $80 \%$ & $0.91( \pm 025)$ & $4.47( \pm 0.51)^{*}$ \\
\hline & $120 \%$ & $1.29( \pm 0.21)$ & $5.51( \pm 0.40)^{*}$ \\
\hline \multirow[t]{4}{*}{ Catalase $\left(\mathrm{mg} \mathrm{gFW}^{-1}\right)$} & $10 \%$ & $126.00( \pm 8.92) \mathrm{b}$ & $21.44( \pm 3.91)^{*}$ \\
\hline & $40 \%$ & $52.09( \pm 4.92) \mathrm{a}$ & $17.92( \pm 3.83)$ \\
\hline & $80 \%$ & $76.38( \pm 9.79) \mathrm{a}$ & $46.72( \pm 10.60)$ \\
\hline & $120 \%$ & $75.50( \pm 15.27) \mathrm{a}$ & $31.23( \pm 8.67)^{*}$ \\
\hline \multirow[t]{4}{*}{$\mathrm{APX}\left(\mu \mathrm{mol} \mathrm{gFW}^{-1} \min ^{-1}\right)$} & $10 \%$ & $2.45( \pm 0.66)$ & $6.81( \pm 0.69)^{*}$ \\
\hline & $40 \%$ & $4.40( \pm 0.84)$ & $5.29( \pm 0.78)$ \\
\hline & $80 \%$ & $0.73( \pm 0.06)$ & $5.56( \pm 0.60)^{*}$ \\
\hline & $120 \%$ & $3.71( \pm 1.02)$ & $6.49( \pm 0.64)$ \\
\hline \multirow[t]{4}{*}{ GPOx $\left(\mu \mathrm{mol} \mathrm{ml}{ }^{-1} \operatorname{prot}^{-1} \min ^{-1}\right)$} & $10 \%$ & $3.48( \pm 0.65)$ & $1.61( \pm 0.40)$ \\
\hline & $40 \%$ & $1.88( \pm 0.35)$ & $2.18( \pm 0.44)$ \\
\hline & $80 \%$ & $1.64( \pm 0.25)$ & $3.03( \pm 1.02)$ \\
\hline & $120 \%$ & $2.40( \pm 0.72)$ & $4.03( \pm 0.71)$ \\
\hline
\end{tabular}

\section{Discussion}

Although the differences observed in biomass accumulation were expected, the two species used different strategies to cope with different water regimes. Even though responding similarly regarding aerial growth, the magnitude of response and underlying coping mechanisms seemed to differ, as discussed below.

An invasive species is a strong competitor with native species, and M. minutiflora is of great concern in the Brazilian savanna and in Hawaii (Pivello et al., 1999; D’Antonio, Hughes, \& Vitousek, 2001; Zenni \& Ziller, 2011; Damasceno et al., 2018). For the Cerrado, Silva and Haridasan (2007) and Hoffmann and Haridasan (2008) reported that $M$. minutiflora produced two to three times as much biomass as the herbaceous layer of the native flora. One possible explanation is the high root:shoot ratio shown by M. minutiflora (Figure 1). The large investment in underground biomass was also reported by Silva and Haridasan (2007) and Barger et al. (2003). The former hypothesized that the invasive species is able to recycle the nutrients of senescent leaves more efficiently. This ability, along with its prominent root system and higher water content, can help to understand why $M$. minutiflora tended to show a smaller percentage of dead leaves by the end of the present experiment. Furthermore, the invasive species produced more tillers and leaves, which can confer an advantage in occupying space and displacing native species, for instance by shading adults, seedlings and seeds (Silva \& Castro, 1989; Hoffmann \& Haridasan, 2008).

Water is highly limiting during the dry season in the Cerrado, and during the rainy season the soil may become flooded in campo-limpo areas or along rivers (Rossato et al., 2012). Both a deficit (10\% WHC) and an excess $(120 \%$ WHC) of water seemed to be harmful to these plants growth, but probably through different mechanisms. Plants under drought stress, tend to invest more energy in underground growth (Hsiao \& Xu, 2000; Chaves et al., 2003; Dolferus, 2014), which is in line with the present data for the root: shoot ratio. In contrast, a water-saturated soil creates an anoxic environment for roots (Kennedy, Rumpho, \& Fox, 1992), and in these conditions the present results showed a reduced root: shoot ratio for both species in the 120\% treatment (Figure $1)$. 
Photosynthesis is one of the primary processes that is most affected by abiotic stresses (Dolferus, 2014). The gas-exchange parameters showed that $M$. minutiflora uses water more efficiently, especially at $80 \%$ WHC (Figure 2), which is in accordance with biomass data. This species showed a higher net assimilation rate despite having lower $\mathrm{g}_{\mathrm{s}}$. Santos et al. (2004) found that a pasture invaded by an African grass showed a higher assimilation rate than a grassland Cerrado with small trees and scattered shrubs (campo sujo). On the other hand, the $\mathrm{C}_{\mathrm{i}} / \mathrm{C}_{\mathrm{a}}$ ratio was higher for the native species. These data indicate that the limitation in photosynthesis may result from a reduced efficiency on the $\mathrm{CO}_{2}$ fixation for the native species rather than deficiency in the $\mathrm{CO}_{2}$ intake (Hossain, López-Climent, Arbona, Pérez-Clemente, \& Gómez-Cadenas, 2009). Ennahli and Earl (2005) suggested that physiological limitations to photosynthesis with water stress might result from chloroplast limitation, such as photoinhibition and/or impairment of carbon metabolism.

The native species seems to cope with flooding by opening the stomata further (Figure 2). Grasses have been reported to be intolerant to excess water, and can be damaged by flooding from early life stages to maturity (Baruch, 1994; Capon \& Brock, 2006), unless they are adapted to wetlands (Kersher \& Zedler, 2004). Stomatal conductance was expected to decrease with drought (Flexas, Escalona, \& Medrano, 1999; Maricle, Cobos, \& Campbell, 2007), but this response was not observed here. Quesada et al. (2004) have shown that the Cerrado native flora passes through the dry season with no major reduction of the transpiration rate.

The photochemical activity was evaluated based on the $\mathrm{F}_{\mathrm{v}} / \mathrm{F}_{\mathrm{m}}, \phi_{\text {PSII }}$ and NPQ parameters. The fluorescence data showed that in all situations, leaves maintained a maximum quantum yield of PSII ( $\mathrm{F}_{\mathrm{v}} / \mathrm{F}_{\mathrm{m}}$ values $)$ above 0.7, indicating that photochemistry activity was not severely impaired (Björkman \& Demmig, 1987). Other studies have demonstrated the plasticity of grass species in different environmental conditions, being able to maintain growth (Dias-Filho \& Carvalho, 2000) and the active photosynthesis system (Flexas et al., 1999). In this study, both the maximum and actual quantum yield were lower for the native species, which might partially explain its lower assimilation rate than the invasive species. Surprisingly, $\mathrm{F}_{\mathrm{v}} / \mathrm{F}_{\mathrm{m}}$ was slightly lower in plants under $80 \%$ moisture, the best growth condition, than at $10 \%$. Chaves et al. (2003) explained that leaves that survive drought tend to have a longer life expectancy and higher photosynthetic capacity, optimizing this rate per area.

No effects of drought on NPQ values were found in this study, although other studies have shown increases in NPQ with drought stress (Loggini, Scartazza, Brugnoli, \& Navari-Izzo, 1999; Correia et al., 2014), suggesting that a higher proportion of energy is lost as heat instead of being used to drive photosynthesis. Kronfuß, Polle, Tausz, Havranek, and Wieser (1998), using a similar methodology, also found no effect of drought on leaf chlorophyll content. The higher values of $\mathrm{Chl}_{\mathrm{a}} / \mathrm{Chl}_{\mathrm{b}}$ found in the native species for the $120 \% \mathrm{WHC}$ treatment might reflect adaptation to high light intensity during summer (Ito, Tanaka, Tsuji, \& Tanaka, 1993).

Drought seems to affect the leaves' nutritional status. Melinis minutiflora showed a higher nitrate concentration than S. microstachyum only at $10 \%$ soil moisture. Other studies that measured nitrogen concentration showed similar values, as well as the same pattern of higher concentration in dry soils (Baruch, 1994; Pinheiro, Chaves, $\&$ Ricardo, 2001). The present study found a reduced content of phosphate in for native species under drought, and no effect of water stress on the invasive species' phosphate content. Similarly, Baruch (1994) found no relationship between drought and flood in phosphorus accumulation in leaves of other African grasses. It was not possible to measure the nutritional profile of dead leaves and determine how efficiently they were reutilizing nutrients. Further studies would benefit from these measurements since some evidence shows that M. minutiflora recycles nitrogen more efficiently than native species from senescent leaves (Silva \& Haridasan, 2007). Nevertheless, the significantly lower percentage of dry leaves in M. minutiflora than in S. microstachyum by the end of the experiment supports the hypothesis that M. minutiflora reabsorbs nutrients more efficiently.

Oxidative stress is a consequence of the imbalance between ROS generation and safe detoxification mechanisms. The generation of ROS in plants is triggered by different kinds of environmental stresses, but plants have evolved a host of anti-oxidants and anti-oxidative enzymes to harmlessly dissipate it (Foyer \& Shigeoka, 2011). Lipid peroxidation is expected to increase with stress (Zhang \& Kirkham, 1994) along with the enzymes that are responsible for removing hydrogen peroxide.

Malondialdehyde (MDA) concentration is an important indicator of lipid peroxidation and membrane damage. In this context, the native species showed pronounced oxidative damage and a higher oxidative response than the invasive species, which partially explains the lower energy available to the former to invest in biomass accumulation. The native species showed higher MDA concentrations, indicating higher lipid peroxidation, which was enhanced by the drought and flood-level treatments.

Plants have evolved efficient antioxidant systems to protect themselves from the damaging effects of oxidative stress. These mechanisms employ ROS-scavenging enzymes such as ascorbate peroxidase (APX) and catalase 
(CAT). In the present study, the native species showed higher APX and GST activities, which tended to increase during drought for the native species, while for the invasive species, these activities remained low. On the other hand, the invasive species showed higher activity of CAT than the native species, and the activity of this enzyme was enhanced in the $10 \%$ treatment. Increases in this defense mechanism might aid in reducing cellular damage in invasive species subjected to drought, since the removal of reactive oxygen molecules $\left(\mathrm{H}_{2} \mathrm{O}_{2}\right.$ in the case of CAT) leads to lower levels of MDA and electrolyte leakage under water-stress conditions.

In conclusion, the three questions raised in this study were positively answered. Although both species were affected by soil moisture level, the invasive species $M$. minutiflora performed better than the native $S$. microstachyum under all conditions and seems better adapted to lower soil-water availability. It grows more both above and below ground, showing less evidence of biochemical stress, using water more efficiently by controlling stomata, and maintaining high assimilation rates and a more active photosystem II. The higher nutrient concentrations and delayed leaf senescence seem to indicate that the invasive species assimilated nutrients more efficiently, partially explaining the higher biomass accumulation.

The information generated in the present study helps to understand the relationships between these species and soil moisture levels in their environment. However, under field conditions, it is important to take into account many factors, such as other interacting stress factors and other species, to manage and control invasive species. Further studies would benefit from complementary fieldwork and longer-term laboratory experiments, as well as a design to evaluate interspecific competition design.

\section{Acknowledgements}

We acknowledge the Fundação para Ciência e Tecnologia (FCT, Portugal) for the PhD grant to C Musso (SFRH/ BD/64938/2009) and a Post-doctoral grant to G Pinto (SFRH/BPD/101669/214). GP is funded by national funds (OE), through FCT, in the scope of the framework contract foreseen in numbers 4, 5 and 6 of the article 23, of the Decree-Law 57/2016, of August 29, changed by Law 57/2017, of July 19. We acknowledge the Coordenação de Aperfeiçoamento de Pessoal de Nível Sueprior (CAPES, Brazil) for a grant to AMVM Soares (Project No.A058/2013). Thanks are due for the financial support to CESAM (UID/AMB/50017/2019), to FCT/MCTES through national funds. We also thank IBAMA and the Reserva Ecológica do IBEGE (RECOR) for granting permission for the fieldwork. We thank Diogo de Lima Saraiva, Gabriela Teixeira Todrigues Lira and Anne Costa for revising the text. We also thank the Universidade de Brasilia for collaboration and technical support.

\section{References}

Aires, S. S, Sato, M. N., \& Miranda, H. S. (2013). Seed characterization and direct sowing of native grass species as a management tool. Grass and Forage Science, 69, 470-478. https://doi.org/10.1111/gfs.12077

Almeida, S. P. (1995). Grupos fenológicos da comunidade de gramíneas perenes de um campo cerrado no Distrito Federal Brasil. Pesquisa Agropecuária Brasileira, 30, 1067-1073.

Alpert, P., Bone, E., \& Hoezapfel, C. (2000). Invasiveness, invasibility and the role of environmental stress in the spread of non-native plants. Perspectives in Plant Ecology, Evolution and Systematics, 3, 52-66. https://doi.org/10.1078/1433-8319-00004

Andrade, L. A. Z., Neto, W. N., \& Miranda, H. S. (2002). Effects of fire on the soil seed bank in a cerrado sensu stricto in central Brazil. In D. X. Viegas (Ed.), Fire research and wildland fire safety (pp. 1-7). Netherlands, Rotterdam: Millpress.

Bailey-Serres, J., Lee, S. C., \& Brinton, E. (2012). Waterproofing crops: Effective flooding survival strategies. Plant Physiology, 160, 1698-1709. https://doi.org/10.1104/pp.112.208173

Barger, N. N., D’Antonio, C. M., Ghneim, T., \& Cuevas, E. (2003). Constraints to colonization and growth of the African grass, Melinis minutiflora, in a Venezuelan savanna. Plant Ecology, 167, 31-43. https://doi.org/ 10.1023/A:1023903901286

Baruch, Z. (1994). Responses to drought and flooding in tropical forage grasses. Plant and Soil, 164, 87-96. https://doi.org/10.1007/BF00010115

Bilger, W., \& Björkman, O. (1990). Role of xanthophyll cycle in photoprotection elucidated by measurements of light-induced absorbance changes, fluorescence and photosynthesis in leaves of Hedera canariensis. Photosynthesis Research, 25, 173-185. https://doi.org/10.1007/BF00033159

Björkman, O., \& Demmig, B. (1987). Photon yield of $\mathrm{O}_{2}$ evolution and chlorophyll fluorescence characteristics at $77 \mathrm{~K}$ among vascular plants of diverse origins. Planta, 170, 489-504. https://doi.org/10.1007/ BF00402983 
Bradford, M. (1976). A rapid and sensitive method for the quantitation of microgram quantities of protein utilizing the principle of protein dye binding. Analytical Biochemistry, 72, 248-254. https://doi.org/ 10.1016/0003-2697(76)90527-3

Capon, S. J., \& Brock, M. A. (2006). Flooding, soil seed bank dynamics and vegetation resilience of a hydrologically variable desert floodplain. Freshwater Biology, 51, 206-223. https://doi.org/10.1111/ j.1365-2427.2005.01484.x

Carmona, R., Martins, C. R., \& Fávero, A. P. (1998). Fatores que afetam a germinação de sementes de gramíneas do Cerrado. Revista Brasileira de Sementes, 20, 6-22. https://doi.org/10.17801/0101-3122/rbs.v20n1p16-22

Castillo, F. I., Penel, I., \& Greppin, H. (1984). Peroxidase release induced by ozone in Sedum album leaves. Plant Physiology, 74, 846-851. https://doi.org/10.1104/pp.74.4.846

Chaves, M. M., Maroco, J. P., \& Pereira, J. S. (2003). Understanding plant responses to drought-from genes to the whole plant. Functional Plant Biology, 30, 239-264. https://doi.org/10.1071/FP02076

Clairborne, A. (1985). Catalase activity. In R. A. Greenwald (Ed.), CRC handbook of methods in oxygen radical research (pp. 283-284). Boca Raton, United States: CRC Press.

Correia, B., Pintó-Marijuan, M., Neves, L., Brossa, R., Dias, M. C., Costa, A., ... Pinto, G. (2014). Water stress and recovery in the performance of two Eucalyptus globulus clones: Physiological and biochemical profiles. Physiologia Plantarum, 150, 580-592. https://doi.org/10.1111/ppl.12110

Coutinho, L. M. (1978). O conceito de Cerrado. Revista Brasileira de Botânica, 1, 17-23.

Cruz, A., Pérez, B., Velasco, A., \& Moreno, J. M. (2003). Variability in seed germination at the interpopulation, intrapopulation and intraindividual levels of the shrub Erica australis in response to fire-related cues. Plant Ecology, 169, 93-103. https://doi.org/10.1023/A:102625631

Daehler, C. C. (2003). Performance Comparisons of Co-occurring Native and Invasive Plants: Implications for Conservation and Restoration. Annual Review of Ecology, Evolution and Systematics, 34, 183-211. https://doi.org/10.1146/annurev.ecolsys.34.011802.132403

D’Antonio, C. M., Hughes, R. F., \& Vitousek, P. M. (2001). Factors influencing dynamics of two invasive C4 grasses in seasonally dry Hawaiian woodlands. Ecology, 82, 89-104. https://doi.org/10.1890/0012-9658 (2001)082[0089:FIDOTI]2.0.CO;2

D'Antonio, C. M., \& Vitousek, P. M. (1992). Biological invasions by exotic grasses: The grass fire cycle and global changes. Annual Review of Ecology and Systematics, 23, 63-87. https://doi.org/10.1146/ annurev.es.23.110192.000431

Damasceno, G., Souza, L., Pivello, V. R., Gorgone-Barbosa, E., Giroldo, P. Z., \& Fidelis, A. (2018). Impact of invasive grasses on Cerrado under natural regeneration. Biological Invasions, 20, 3621-3629. https://doi.org/10.1007/s10530-018-1800-6.

Dhindsa, R. S., Plumb-Dhindsa, P., \& Throne, T. A. (1981). Leaf senescence: correlated with increased levels of membrane permeability and lipid peroxidation and decreased levels of superoxide dismutase and catalase. Journal of Experimental Botany, 32, 93-101. https://doi.org/10.1093/jxb/32.1.93

Dias-Filho, M. B., \& Carvalho, C. J. R. (2000). Physiological and morphological responses of Brachiaria spp. to flooding. Revista Agropecuária Brasileira, 35, 1959-1966. https://doi.org/10.1590/S0100-204X2000001 000006

Dolferus, R. (2014). To grow or not to grow: A stressful decision for plants. Plant Science, 229, 247-261. https://doi.org/10.1016/j.plantsci.2014.10.002

Eiten, G. (1972). The cerrado vegetation of Brazil. Botanical Review, 38, 201-341. https://doi.org/10.1007/ BF02859158

Ennahli, S., \& Earl, H. J. (2005). Physiological limitations to photosynthetic carbon assimilation in cotton under water stress. Crop Science, 45, 2374-2382. https://doi.org/10.2135/cropsci2005.0147

Fidelis, A., Lyra, M. F. S., \& Pivello, V. R. (2013). Above- and below-ground biomass and carbon dynamics in Brazilian Cerrado wet grasslands. Journal of Vegetation Science, 24, 356-364. https://doi.org/10.1111/ j.1654-1103.2012.01465.x

Filgueiras, T. S. (1992). Gramíneas forrageiras nativas do Distrito Federal, Brasil. Pesquisa Agropecuária Brasileira, 27, 1103-1111. 
Flexas, J., Escalona, J. M., \& Medrano, H. (1999). Water stress induces different levels of photosynthesis and electron transport rate regulation in grapevines. Plant, Cell and Environment, 22, 39-48. https://doi.org/ 10.1046/j.1365-3040.1999.00371.x

Foyer, C. H., \& Shigeoka, S. (2011). Understanding oxidative stress and antioxidant functions to enhance photosynthesis. Plant Physiology, 155, 93-100. https://doi.org/10.1104/pp.110.166181

Funk, J. L., Cleland, E. E., Suding, K. N., \& Zavaleta, E. S. (2008). Restoration through reassembly: Plant traits and invasion resistance. Trends in Ecology and Evolution, 23, 695-703. https://oi.org/10.1016/ j.tree.2008.07.013

Going, B. M., Hillerislambers, J., \& Levine, J. N. (2009). Abiotic and biotic resistance to grass invasion in serpentine annual plant communities. Oecologia, 159, 839-847. https://doi.org/10.1007/s00442-008-1264-y

Habig, W. H., \& Jakoby, W. B. (1981). Assays for differentiation of glutathione S transferases. Methods in Enzymology, 77, 398-405. https://doi.org/10.1016/S0076-6879(81)77053-8

Hoffmann, W. A., \& Haridasan, M. (2008). The invasive grass, Melinis minutiflora, inhibits tree regeneration in a Neotropical savanna. Austral Ecology, 33, 29-36. https://doi.org/10.1111/j.1442-9993.2007.01787.x

Hossain, Z., López-Climent, M. F., Arbona, V., Pérez-Clemente, R. M., \& Gómez-Cadenas, A. (2009). Modulation of the antioxidant system in citrus under waterlogging and subsequent drainage. Journal of Plant Physiology, 166, 1391-1404. https://doi.org/10.1016/j.jplph.2009.02.012

Howcroft, C., Gravato, C., Amorim, M., Novais, S., Soares, A., \& Guilhermino, L. (2011). Biochemical characterization of cholinesterases in Enchytraeus albidus and assessment of in vivo and in vitro effects of different soil properties, copper and phenmedipham. Ecotoxicology, 20, 119-130. https://doi.org/10.1007/ s10646-010-0562-4

Hsiao, T., \& Xu, L. K. (2000). Sensitivity of growth of roots versus leaves to water stress: Biophysical analysis and relation to water transport. Journal of Experimental Botany, 51, 1595-1616. https://oi.org/10.1093/ jexbot/51.350.1595

IOS (International Organization for Standardization). (1995). Determination of the effects of pollutants on soil flora-Part 2: Effects of chemicals on the emergence and growth of higher plants. Soil quality, ISO 11269-2. Geneva, Switzerland.

Ito, H., Tanaka, Y., Tsuji, H., \& Tanaka, A. (1993). Conversion of Chlorophyll b to Chlorophyll a by isolated cucumber etioplasts. Archives of Biochemistry and Biophysics, 306, 148-151. https://doi.org/10.1006/ abbi.1993.1492

Kennedy, R. A., Rumpho, M. E., \& Fox, T. C. (1992). Anaerobic Metabolism in Plants. Plant Physiology, 100, 1-6. https://doi.org/10.1104/pp.100.1.1

Kersher, S. M., \& Zedler, J. B. (2004) Flood tolerance in wetland angiosperms: A comparison of invasive and noninvasive species. Aquatic Botany, 80, 89-102. https://doi.org/10.1016/j.aquabot.2004.08.003

Kronfuß, G., Polle, A., Tausz, M., Havranek, W.M., \& Wieser, G. (1998). Effects of ozone and mild drought stress on gas exchange, antioxidants and chloroplast pigments in current-year needles of young Norway spruce [Picea abies (L.) Karst.]. Trees, 12, 482-489. https://doi.org/10.1007/PL00009730

Loggini, B., Scartazza, A., Brugnoli, E., \& Navari-Izzo, F. (1999). Antioxidative defense system, pigment composition, and photosynthetic efficiency in two wheat cultivars subjected to drought. Plant Physiology, 119, 1091-1099. https://doi.org/10.1104/pp.119.3.1091

Loureiro, S., Santos, C., Pinto, G., Costa, A., Monteiro, M., Nogueira, A. J. A., \& Soares, A. M. V. M. (2006). Toxicity assessment of two soils from Jales mine (Portugal) using plants: Growth and biochemical parameters. Archives of Environmental Contamination and Toxicology, 50, 182-190. https://doi.org/10.1007/ s00244-004-0261-3

Maricle, B. R., Cobos, D. R., \& Campbell, C. S. (2007). Biophysical and morphological leaf adaptations to drought and salinity in salt marsh grasses. Environmental and Experimental Botany, 60, 458-467. https://doi.org/10.1016/j.envexpbot.2007.01.001

Martins, C. R. (2006). Caracterização e manejo da gramínea Melinis minutiflora P. Beauv. (Capim Gordura): Uma espécie invasora do Cerrado (Unpublished doctoral dissertation, Universidade de Brasilia, Brasilia, Brazil). 
Meekins, J. F., \& McCarthy, B. C. (2001). Effect of environmental variation on the invasive success of a nonindigenous forest herb. Ecological Applications, 11, 1336-1348. https://doi.org/10.1890/1051-0761 (2001)011[1336:EOEVOT]2.0.CO;2

Mittler, R., Vanderauwera, S., Gollery, M., \& Van Breusegem, F. (2004). Reactive oxygen gene network of plants. Trends in Plant Science, 9, 490-498. https://doi.org/10.1016/j.tplants.2004.08.009

Moreira, B., Tavsanoglu, Ç., \& Pausas, J. G. (2012). Local versus regional intraspecific variability in regeneration traits. Oecologia, 168, 671-677. https://doi.org/10.1007/s00442-011-2127-5

Munhoz, C. B. R., \& Felfili, J. M. (2005). Phenology of the herbaceous layer in a campo sujo community in the Fazenda Água Limpa, Federal District, Brazil. Acta Botanica Brasilica, 19, 979-988. https://doi.org/ 10.1590/S0102-33062005000400031

Munhoz, C. B. R., \& Felfili, J. M. (2006). Fitossociologia do estrato herbáceo-subarbustivo de uma área de campo sujo no Distrito Federal, Brasil. Acta Botanica Brasilica, 20, 671-685. https://doi.org/10.1590/ S0102-33062006000300017

Myers, N., Mittermeier, R. A., Mittermeier, C. G., Fonseca, G. A. B., \& Keny, J. (2000). Biodiversity hotspots for conservation priorities. Nature, 403, 853-858. https://doi.org/10.1038/35002501

Nakano, Y., \& Asada, K. (1981). Hydrogen peroxide is scavenged by ascorbate specific peroxides in spinach chloroplasts. Plant Cell Physiology, 22, 867-880. https://doi.org/10.1093/oxfordjournals.pcp.a076232

Pinheiro, C., Chaves, M. N., \& Ricardo, C. P. (2001). Alterations in carbon and nitrogen metabolism induced by water deficit in the stems and leaves of Lupinus albus L. Journal of Experimental Botany, 52, 1063-1070. https://doi.org/10.1093/jexbot/52.358.1063

Pivello, V. R., Shida, C. N., \& Meirelles, S. T. (1999). Alien grasses in Brazilian savannas: A threat to the biodiversity. Biodiversity and Conservation, 8, 1281-1294. https://doi.org/10.1023/A:1008933305857

Quesada, C. A., Miranda, A. C., Hodnett, M. G., Santos, A. J. B., Miranda, H. S., \& Breyer, L. M. (2004). Seasonal and depth variation of soil moisture in a burned open savanna (campo sujo) in central Brazil. Ecological Applications, 14, 33-41. https://doi.org/10.1890/01-6017

Ribeiro, J. F., \& Walter, B. M. T. (1998). Fitofisionomias do bioma Cerrado. In S. M. Sano, \& S. P. Almeida (Eds.), Cerrado: Ambiente e flora. Brasilia, Brazil: Embrapa Informação Tecnológica.

Rossato, D. R., Silva, L. C. R., Villalobos-Veja, R., Sternberg, L. S. L., \& Franco, A. C. (2012). Depth of water uptake in woody plants relates to groundwater level and vegetation structure along a topographic gradient in a neotropical savanna. Environmental and Experimental Botany, 77, 259-266. https://oi.org/10.1016/ j.envexpbot.2011.11.025

Santos, A. J. B., Quesada, C. A., Da Silva, G. T., Maia, J. F., Miranda, H. S., Miranda, A. C., \& Lloyd, J. (2004). High rates of net assimilation by Brachiaria parture in the Brazilian Cerrado. Global Change Biology, 10, 877-885. https://doi.org/10.1111/j.1529-8817.2003.00777.x

Silva, J. F., \& Castro, F. (1989). Fire, growth and survivorship in a Neotropical savanna grass Andropogon semiberbis in Venezuela. Journal of Tropical Ecology, 5, 387-400. https://doi.org/10.1017/ S0266467400003849

Silva, J. S. O., \& Haridasan, M. (2007). Acúmulo de biomassa aérea e concentraçãoo de nutrientes em $M$. minutiflora P. Beauv. e gramíneas nativas do cerrado. Revista Brasileira de Botânica, 30, $337-344$. https://doi.org/10.1590/S0100-84042007000200016

Simões, M., \& Baruch, Z. (1991). Responses to simulated herbivory and water stress in two tropical C4 grasses. Oecologia, 88, 173-180. https://doi.org/10.1007/BF00320808

Sims, D. A., \& Gamon, J. A. (2002). Relationships between leaf pigment content and spectral reflectance across a wide range of species, leaf structures and developmental stages. Remote Sensing of Environment, 81, 337-354. https://doi.org/10.1016/S0034-4257(02)00010-X

Suzuki, N., Koussevitzky, S., Mittler, R., \& Mittler, G. (2012). ROS and redox signaling in the response of plants to abiotic stress. Plant Cell Environment, 35, 259-270. https://doi.org/10.1111/j.1365-3040.2011.02336.x

Tester, M., \& Basic A. (2005). Abiotic Stress Tolerance in Grasses. From Model Plants to Crop Plants. Plant Physiology, 137, 791-793. https://doi.org/10.1104/pp.104.900138 
Van Kooten, O., \& Snel, J. F. H. (1990). The use of chlorophyll fluorescence nomenclature in plant stress physiology. Photosynthesis Research, 25, 147-150. https://doi.org/10.1007/BF00033156

Warren, C. R. (2008). Rapid measurement of chlorophylls with a microplate reader. Journal of Plant Nutrition, 31, 1321-1332. https://doi.org/10.1080/01904160802135092

Wickham, H. (2009). ggplot2: Elegant graphics for data analysis. Springer-Verlag, New York. https://doi.org/10.1007/978-0-387-98141-3

Zenni, R. D., \& Ziller, S. R. (2011). An overview on invasive plants in Brazil. Revista Brasileira de Botânica, 34, 431-446. https://doi.org/10.1590/S0100-84042011000300016

Zhang, J., \& Kirkham, M. B. (1994) Drought-stress-induced changes in activities of superoxide dismutase, catalase, and peroxidase in wheat species. Plant Cell Physiology, 35, 785-791. https://doi.org/10.1093/ oxfordjournals.pcp.a078658

\section{Copyrights}

Copyright for this article is retained by the author(s), with first publication rights granted to the journal.

This is an open-access article distributed under the terms and conditions of the Creative Commons Attribution license (http://creativecommons.org/licenses/by/4.0/). 